OPEN ACCESS

ISSN 2548-3501 (online)

Edited by:

Eny Maryanti

Reviewedby:

Supriyati

${ }^{*}$ Correspondence: sriwahjuni@umm.ac.id

Received: 17 Maret 2021 Accepted:20 June 2021 Published: 31 July 2021

Citation:

Latifah dan Abitama (2021) Keterlibatan Pemakai, Pelatihan Dan Pendidikan, Serta Dukungan Manajemen Puncak Terhadap Kinerja Sistem Informasi Akuntansi

\section{Keterlibatan Pemakai, Pelatihan Dan Pendidikan, Serta Dukungan Manajemen Puncak Terhadap Kinerja Sistem Informasi Akuntansi}

\author{
Sri Wahjuni Latifah*, Wibi Abitama
}

Universitas Muhammadiyah Malang, Indonesia

This research was conducted with the aim of analyzing the influence of the involvement of users of accounting information systems, training and education, as well as top management support to the performance of accounting information systems. The research was conducted at Sentani Oncology Hospital Malang. This research is an associative research with quantitative method approach with fifty-four (54) employees in the hospital. The method of selecting respondents is done by accidental sampling technique. The data was obtained by disseminating questionnaires to respondents and then the data was analyzed with descriptive statistical analysis, validity and reliability tests and hypothesis testing conducted with PLS warpls 7 software. The results showed there was a positive and significant influence between the involvement of system users on the performance of accounting information systems, there was a positive and significant influence between training and education on the performance of accounting information systems and there was a positive and significant influence between the support of top management on the performance of accounting information systems. The limitation of this study is only done on employees involved in the use of accounting information system at Sentani Hospital Oncology Malang with a relatively small number of respondents, so it cannot be used to generalize the results of the study.

Keywords: user involvement, training and education, top management, performance of the accounting information system

Penelitian ini dilakukan dengan tujuan menganalisis pengaruh keterlibatan pemakai system informasi akuntansi, pelatihan dan pendidikan, serta dukungan manajemen puncak terhadap kinerja sistem informasi akuntansi. Penelitian dilakukan pada RS Onkologi Sentani Malang. Penelitian ini merupakan penelitian asosiatif dengan pendekatan metode kuantitatif dengan responden lima puluh empat (54) karyawan di RS tersebut. Metode pemilihan responden dilakukan dengan tehnik accidental sampling. Data diperoleh dengan menyebar kuesioner kepada responden selanjutnya data dianalis dengan analisis statistik deskriptif, uji validitas dan reliabilitas dan pengujian hipotesis dilakukan dengan software PLS warpls 7. Hasil penelitian menunjukkan terdapat pengaruh positif dan signifikan antara keterlibatan pemakai sistem terhadap kinerja sistem informasi akuntansi, terdapat pengaruh positif dan 
signifikan antara pelatihan dan pendidikan terhadap kinerja sistem informasi akuntansi serta terdapat pengaruh positif dan signifikan antara dukungan manajemen puncak terhadap kinerja sistem informasi akuntansi. Keterbatasan penelitian ini adalah hanya dilakukan pada karyawan yang terlibat dalam penggunaan sistem informasi akuntansi di Rumah Sakit Onkologi Sentani Malang dengan jumlah responden yang relatif sedikit, sehingga tidak dapat digunakan untuk menggeneralisir hasil penelitian.

Keywords: keterlibatan pemakai, pelatihan dan pendidikan, manajemen puncak, kinerja sistem informasi akuntansi 


\section{PENDAHULUAN}

Perkembangan teknologi informasi semakin maju dan pesat dengan adanya perangkat teknologi yang bisa mempermudah manusia dalam melakukan kegiatan. Pertumbuhan perusahaan dalam meningkatkan pertumbuhan ekonomi, stabilitas nasional dan kesejahteraan rakyat dapat dipengaruhi dengan adanya perkembangan teknologi informasi. Dengan adanya perkembangan pada informasi akuntansi menyebabkan kebutuhan informasi semakin berkemban bbagi pihak-pihak yang mempunyai kepentingan dan membutuhkan proses serta kinerja yang mempunyai kualitas dalam mengahsilkan informasi.

Sistem informasi akuntansi membantu rumah sakit dalam proses akuntansinya, mulai proses pencatatan transaksi pembayaran instalasi rawat inap, pencatatan transaksi pembayaran instalasi rawat jalan, dan pencatatan transaksi pembayaran apotek. Sistem informasi akuntansi rumah sakit sangat penting untuk menunjang infiormasi akuntansi yang akurat dan relevan untuk pengambilan keputusan manajemen rumah sakit. Hal ini karena tujuan rumah sakit adalah untuk melayani masyarakat sehingga diperlukan informasi yang akurat dalam pengolahan data dan sistem informasi akuntansi untuk menunjang layanan rumah sakit yang efektif. Seperti diketahui bahwa "tujuan sistem informasi akuntansi adalah meningkatkan keandalan (reability) informasi akuntansi dan untuk menyediakan informasi akuntansi yang lengkap dan tepat tentang pertanggungjawaban organisasi dan memberikan perlindungan aset organisasi” (Mulyadi, 2010)

Suatu perusahaan harus melakukan penilaian kinerja sistem informasi akuntansi untuk membantu mengevaluasi keberhasilan sistem informasi akuntansi itu sendiri, sehingga dapat memberikan nilai tambah untuk meningkatkan kinerja perusahaan. "Penilaian kinerja sistem informasi akuntansi merupakan hal penting sehingga perlu mengevaluasi faktorfaktor yang mempengaruhi kinerja sistem informasi akuntansi dilakukan secara cepat dan tepat" (Utama \& Suardhika, 2009). Beberapa faktor yang dapat mempengaruhi kinerja sistem informasi akuntansi yaitu keterlibatan pemakai, adanya pelatihan dan pendidikan, serta adanya dukungan manajemen puncak.

Menurut Rivaningrum \& Mahmud (2015)"keterlibatan pemakai dalam pengembangan system merupakan bentuk keterlibatan mental dan emosi pegawai dalam situasi kelompok yang memberikan kontribusi pada tujuan kelompok serta bertanggungjawab di dalam pengembangan SIA. Sebaik apapun sistem informasi yang dibuat, jika dalam perancangan sistemnya tidak melibatkan factor sumber daya manusia sebagai pemakai, maka akan terjadi beberapa hambatan yang disebabkan karena ketidaksesuaian antara system yang telah dibuat dengan kebutuhan para pemakai. Untuk itu, dengan semakin besar kontribusi pemakai terlibat dalam proses pengembangan sistem, maka akan meningkatkan kinerja sistem informasi akuntansi tersebut.

Almilia dkk., (2014) mengemukakan bahwa untuk meningkatkan kinerja sistem informasi akuntansi pada sebuah perusahaan, diperlukan program pendidikan dan pelatihan bagi para pemakainya. Dalam suatu pelatihan orientasi atau penekanannya pada tugas yang harus dilaksanakan, sedangkan pendidikan lebih pada pengembangan umum (Dalimunthe dkk., 2014). Menurut (Komara, 2005), "sebuah organisasi dalam pengembangan sistem informasi akuntansi harus memiliki program pendidikan dan pelatihan bagi pemakai sistem informasi akuntansi". Karena dengan adanya pendidikan dan pelatihan yang tinggi, pengguna bisa memperoleh kemampuan untuk mengidentifikasi persyaratan informasi, serta keterbatasan sistem informasi dan kemampuan ini dapat mengarah pada peningkatan kinerja. Tujuan program pendidikan dan pelatihan pemakai yaitu meningkatkan kemampuan dan pemahaman pemakai terhadap sistem informasi akuntansi yang akan digunakan.

"Dukungan manajemen puncak merupakan keterlibatan manajer dalam pelaksanaan proyek pengembangan sistem dan menyediakan sumber daya yang diperlukan" (Saebani \& Muliawati, 2016). Menurut Arpan dan Isaac dalam (Shien, $\underline{2015)}$, "dukungan manajemen puncak merupakan faktor penting yang menentukan efektivitas sistem informasi organisasi." "Dukungan manajemen puncak menggambarkan hak, tugas, kewajiban, dan perilaku yang sesuai dengan orang yang memegang posisi tertentu dalam konten sosial tertentu, dimana peran manajemen puncak sebagai pengaruh keberhasilan implementasi sistem baru dan pengembangan daya inovatif bawahan". Saebani \& Muliawati, (2016). "Semakin besar dukungan yang diberikan manajemen puncak akan meningkatkan kinerja sistem informasi akuntansi dikarenakan adanya hubungan yang positif antara dukungan manajemen puncak dalam proses pengembangan dan pengoperasian sistem informasi akuntansi dengan kinerja sistem informasi akuntansi" (Chomasatu, 2014).

Beberapa penelitian tentang pengaruh keterlibatan pemakai, program pelatihan dan pendidikan pengguna, dan dukungan manajemen puncak terhadap kinerja sistem informasi akuntansi telah dilakukan oleh beberapa peneliti terdahulu, diantaranya yaitu: Rivaningrum \& Mahmud, (2015) yang menyatakan bahwa "keterlibatan pengguna dalam pengembangan sistem, program pendidikan dan pelatihan pengguna, serta dukungan manajemen puncak berpengaruh positif terhadap kinerja SIA", Ane \& Anggraini, (2012) yang menyatakan bahwa "keterlibatan pemakai dalam proses pengembangan sistem, dukungan pimpinan bagian, program pelatihan dan pendidikan pemakai, secara bersama -sama berpengaruh signifikan terhadap kinerja sistem informasi akuntansi". Utama \& Suardhika (2009) yang "menyatakan bahwa "keterlibatan pemakai berpengaruh terhadap pemakaian sistem, namun dukungan manajemen puncak, dan program pendidikan dan pelatihan tidak berpengaruh terhadap pemakaian system". Prabowo dkk., (2013) yang menyatakan bahwa "pelatihan dan pendidikan pengguna serta dukungan top management memiliki pengaruh terhadap kinerja sistem informasi akuntansi, sedangkan keterlibatan pengguna dalam pengembangan sistem tidak memiliki pengaruh terhadap kinerja sistem informasi akuntansi". Berbeda dengan temuan penelitian Dwinda, (2015) bahwa keteribatan pengguna tidak berpengaruh pada efektivitas sistem informasi akuntansi. Demikian juga penelitian Almillia \& Briliantien (2007) “ tidak menemukan hubungan keterlibatan pengguna terhadap kinerja sistem informasi akuntansi”.

Dari beberapa penelitian tersebut, ada beberapa variabel hasilnya tidak konsisten mempengaruhi kinerja sistem informasi 
akuntansi. Penelitian ini dilakukan untuk mengkaji ulang tentang kinerja sistem informasi akuntansi dengan obyek pada Rumah Sakit Onkologi Sentani Hal ini penting karena organisasi rumah sakit memiliki kakateristik yang berbeda dengan industri lain, sehingga ada kemungkinan faktor yang mepengaruhi kinerja sistem informasi akuntansinya berbeda. Selain itu penelitian menggunakan model analisis jalur menggunakan Wrap PLS untuk melihat pengaruh indikator keterlibatan pemakai pelatihan dan pendidikan serta dukungan manajemen puncak terhadap kinerja sistem informasi akuntansi sedangkan penelitian sebelumnya menggunkan pengujian dengan softaware SPPS yang memerlukan pengujian asumsi klasik dan terkadang tidak sesuai sehingga terpaksa datanya dinormalkan Penelitian sebelumnya lebih banyak dilakukan pada industry perbankan dan lembaga pemerintahan. Tujuan penelitian ini adalah untuk mengetahui pengaruh keterlibatan pemakai, pelatihan dan pendidikan, serta dukungan dukungan manajemen puncak., terhadap kinerja sistem informasi akuntansi. Dengan adanya penelitian ini diharapkan dapat meningkatkan faktor-faktor yang dapat mempengaruhi kinerja sistem informasi akuntansi. ini:

Kerangka pemikiran dapat dilihat pada Figure 1 berikut

\section{[Figure 1 about here.]}

\section{Keterlibatan Pemakai}

"Pemakai atau pengguna merupakan bagian yang tidak dapat dilepaskan dari keberhasilan penerapan suatu sistem atau teknologi. Menyadari bahwa operasionalisasi teknologi komputer menyangkut aspek manusia dan dampak perubahan yang disebabkannya, adalah penting untuk memperhatikan keberadaan manusia dalam pemanfaatan suatu teknologi" (Chomasatu, 2014). Hasil penelitian ini sesuai dengan penelitian sebelumnya yang dilakukan oleh (Rivaningrum \& Mahmud, 2015) yang mengatakan bahwa "keterlibatan pemakai berpengaruh positif terhadap kinerja sistem informasi akuntansi". Kemudian hasil penelitian ini juga didukung oleh penelitian yang dilakukan (Manek \& Santoso, 2019), yang membuktikan bahwa "keterlibatan pemakai memiliki efek yang positif terhadap kinerja sistem informasi akuntansi". Berdasarkan uraian tersebut, dapat disimpulkan hipotesis sebagai berikut:

$\mathrm{H}_{1}$ : Keterlibatan pemakai berpengaruh positif terhadap kinerja sistem informasi akuntansi

\section{Pelatihan dan Pendidikan}

"Tujuan diadakan program pendidikan dan pelatihan yaitu untuk meningkatkan kemampuan dan pemahaman pemakai terhadap sistem informasi akuntansi yang akan digunakan. Selain itu juga akan membuat pemakai merasa lebih puas dan akan menggunakan sistem yang telah dikuasai dengan baik dan lancar. Sehingga membantu menyelesaikan pekerjaan pemakai secara lebih efektif dan efisien" (Prabowo dkk., 2013). Jen Tjhai Fung dalam (Ladewi \& Nurhayati, 2015), mengemukakan bahwa "sistem informasi akuntansi kinerja akan lebih tinggi jika program pelatihan dan pendidikan pengguna diperkenalkan." Hal ini didukung oleh penelitian (Chomasatu, 2014) yang memperoleh hasil bahwa "pendidikan dan pelatihan berpengaruh secara positif terhadap kinerja sistem informasi akuntans". Berdasarkan uraian tersebut, dapat disimpulkan hipotesis sebagai berikut:
$\mathrm{H}_{2}$ : Pelatihan dan pendidikan berpengaruh positif terhadap kinerja sistem informasi akuntansi

\section{Dukungan Manajemen Puncak}

"Dukungan manajemen puncak menggambarkan hak, tugas, kewajiban, dan perilaku yang sesuai dengan orang yang memegang posisi tertentu dalam konten sosial tertentu, dimana peran manajemen puncak sebagai pengaruh keberhasilan implementasi sistem baru dan pengembangan daya inovatif bawahan". (Saebani \& Muliawati, 2016). Hasil penelitian (Mardiana dkk., 2014) mengemukakan "dukungan manajemen puncak dalam proses pengembangan sistem informasi dan pengorganisasian sistem informasi dalam perusahaan akan meningkatkan keinginan pemakai untuk menggunakan sistem informasi yang ada dan merasa puas dalam menggunakan sistem tersebut, sehingga akan meningkatkan kinerja sistem informasi akuntansinya". Hal ini juga didukung oleh penelitian (Ferawati dan Purwanto, 2015), yang menyatakan bahwa "dukungan manajemen puncak berpengaruh signifikan terhadap kinerja sistem informasi”. Berdasarkan uraian tersebut, dapat disimpulkan hipotesis sebagai berikut:

$\mathrm{H}_{3}$ : Dukungan manajemen puncak berpengaruh positif terhadap kinerja sistem informasi akuntansi.

\section{METODE}

Penelitian ini merupakan penelitian asosiatif dengan pendekatan kuantitatif. Data diporeleh dari jawaban responden yang merupakan hasil dari pengisian kuesioner yang disebarkan secara langsung oleh peneliti. Variabel penelitian ini terdiri dari variabel dependen dan independen. Variabel dependennya adalah kinerja sistem informasi akuntansi, sedangkan variabel independennya adalah keterlibatan pemakai, pelatihan dan pendidikan, dan dukungan manajemen puncak.

Berikut variabel penelitian dan indikatornya:

\section{[Table 1 about here.]}

\section{Populasi dan Sampel}

Populasi dalam penelitian ini adalah seluruh pengguna sistem informasi akuntansi pada Rumah Sakit Onkologi Sentani Kota Malang. Sedangkan sampel dalam penelitian ini adalah seluruh populasi yang ada atau karyawan di Rumah Sakit Onkologi Sentani yang terlibat dalam penggunaan sistem informasi akuntansi yaitu sebanyak lima puluh empat (54) orang. Teknik pengambilan sampel dalam penelitian ini adalah teknik accidental sampling (convenience sampling). Menurut (Santoso, T., \& Tjiptono, 2001) "accidental sampling (convenience sampling) adalah prosedur sampling yang memilih sampel dari orang atau unit yang paling mudah dijumpai atau diakses"

Teknik pengumpulan data dalam penelitian ini adalah metode kuesioner tertutup dengan menggunakan skala likert 5 respon. (Sugiyono, 2016) menjelaskan "skala likert digunakan untuk mengukur sikap, pendapat, dan persepsi seseorang atau sekelompok orang tentang fenomena sosial., dengan skala Likert, maka variabel yang akan diukur dijabarkan menjadi indikator variabel. Pengukuran variabel dilakukan dengan menggunakan skala likert 5 jenjang dengan menggunakan alternatif jawaban sebagai berikut:(SS): Sangat Setuju(skor5);(S): Setuju(skor 4); (CS): Cukup Setuju(skor 
3); (TS): Tidak Setuju(skor 2) dan (STS): Sangat Tidak Setuju(skor 1)."

Teknik analisis data dengan menggunakan analisis statistik deskriptif dan pengujian hipotesis dengan software Warp-PLS 7.0. Pengujian hipotesis dimulai dari tahap menguji reliabilitas dan validitas dari indikator-indikator pembentuk konstruk laten dengan pengujian Outer model. Selanjutnya dilakukan pengujian Inner model bertujuan untuk memprediksi hubungan antar variabel laten dengan melihat seberapa besar variance yang dapat dijelaskan dan untuk mengetahui signifikansi dari $P$-value. Bedasar hasil inner model maka dapat disimpulkan bahwa hipotesis dinyatakan diterima jika $\mathrm{P}$ value memiliki nilai kurang dari $5 \%(0,05)$.

\section{HASIL DAN PEMBAHASAN}

Berdasarkan hasil penelitian dari lima puluh empat (54) responden pada karyawan Rumah Sakit Onkologi Sentani Malang dapat diketahui gambaran umum sebagai berikut: deskripsi responden berdasarkan jenis kelamin diketahui bahwa responden berjenis kelamin laki-laki sebanyak 21 responden atau 38,9\% dan responden berjenis kelamin perempuan sebanyak 33 responden atau $61,1 \%$ dari keseluruhan responden. Sedangkan berdasarkan latar belakang pendidikan diketahui bahwa sebagian besar responden memiliki latar belakang pendidikan tingkat sarjana (S1) sebanyak 28 responden $(51,8 \%)$, kemudian 13 responden $(24,2 \%)$ memiliki latar belakang pendidikan tingkat SMA, 9 responden $(16,6 \%)$ memiliki latar belakang tingkat pendidikan diploma (D3). Dan 4 responden $(7,4 \%)$ yang memiliki latar belakang pendidikan tingkat pasca sarjana. Deskripsi responden berdasarkan profesi diketahui bahwa proporsi terbesar responden dalam penelitian ini yaitu responden yang berprofesi sebagai tenaga non medis dengan jumlah responden sebanyak 16 orang dengan presentase $29,7 \%$, berprofesi sebagai tenaga non keperawatan berjumlah 14 orang dengan presentase $25,9 \%$, sebagai tenaga para medis berjumlah 13 orang dengan presentase $24,1 \%$ dan sebagai tenaga medis berjumlah 11 responden dengan presentase $20,3 \%$.

Berdasarkan deskripsi mengenai variabel keterlibatan pemakai, pelatihan dan pendidikan, dukungan manajemen puncak, serta kinerja sistem informasi akuntansi. Berdasarkan keseluruhan item keterlibatan pemakai diperoleh nilai grand mean sebesar 3,77 yang termasuk dalam kriteria interval baik. Berdasarkan keseluruhan item pelatihan dan pendidikan diperoleh nilai grand mean sebesar 4,3 yang termasuk dalam kriteria interval baik. Berdasarkan keseluruhan item dukungan manajemen puncak diperoleh nilai grand mean sebesar 4,09 yang termasuk dalam kriteria interval baik. Berdasarkan keseluruhan item kinerja sistem informasi akuntansi diperoleh nilai grand mean sebesar 3,59 yang termasuk dalam kriteria interval baik

\section{Hasil Analisis PLS}

\section{Evaluasi Model Pengukuran (Outer Model)}

Outer model dilakukan untuk menilai reliabilitas dan validitas dari indikator-indikator pembentuk konstruk laten.

\section{1) Indicator Reliability}

Indikator dalam mengukur variabel ditunjukkan oleh besarnya loading factor yang harus bernilai positif dan lebih besar dari 0,60 yang berarti memenuhi kriteria indicator reliability.

\section{[Table 1 about here.]}

Berdasarkan tabel 1, dapat diketahui bahwa indikator-indikator dari variabel keterlibatan pemakai $\left(\mathrm{X}_{1}\right)$, pelatihan dan pendidikan $\left(\mathrm{X}_{2}\right)$, dukungan manajemen puncak $\left(\mathrm{X}_{3}\right)$, serta kinerja sistem informasi akuntansi (Y) menghasilkan loading factor yang lebih besar dari 0.60. Dengan demikian indikatorindikator dinyatakan reliabel dalam mengukur keempat variabel tersebut.

\section{Convergent Validity}

Convergent validity dimaksudkan untuk menguji korelasi antar item/indikator dalam mengukur konstruk.

\section{[Table 2 about here.]}

Berdasarkan tabel 2, dapat diketahui bahwa seluruh variabel menghasilkan nilai Average Variance Extracted (AVE) yang lebih besar dari 0.5. Dengan demikian semua indikator yang mengukur variabel tersebut dinyatakan valid.

\section{Evaluasi Model Struktural (Inner Model)}

Inner model bertujuan untuk memprediksi hubungan antar variabel laten dengan melihat seberapa besar variance yang dapat dijelaskan dan untuk mengetahui signifikansi dari $P$ value.

\section{Effect Size}

Effect size digunakan untuk mengetahui besarnya proposi variance variabel eksogen tertentu terhadap variabel endogen.

\section{[Table 3 about here.]}

Berdasarkan tabel 3, nilai effect size yang dihasilkan variabel $X_{1}$ terhadap variabel $Y$ adalah sebesar 0,227 dan kurang dari 0,35 yang berarti termasuk dalam kategori menengah. Nilai effect size yang dihasilkan variabel $\mathrm{X}_{2}$ terhadap $\mathrm{Y}$ adalah sebesar 0,0095 dan kurang dari 0,15 yang berarti termasuk dalam kategori kecil. Kemudian nilai effect size yang dihasilkan variabel $\mathrm{X}_{3}$ terhadap $\mathrm{Y}$ adalah sebesar 0,093 dan kurang dari 0,15 yang berarti termasuk dalam kategori kecil.

\section{Goodness of fit (GoF)}

Goodness of fit (GoF) digunakan untuk mengukur evaluasi fit model secara keseluruhan.

\section{[Table 4 about here.]}

Berdasarkan hasil pada tabel 4, diketahui bahwa indeks Average Path Coefficient (A $\overline{\mathrm{PC}})$ menghasilkan nilai $\mathrm{p}$ value sebesar 0,003, Average R-Squared (ARS), dan Average Adjusted $R$-Squared (AARS) menghasilkan nilai $\mathrm{p}$ value sebesar $<0.001$. Hal ini menunjukkan nilai $\mathrm{p}$ value tersebut lebih kecil dari 0,05. Dengan demikian berdasarkan indeks Average Path Coefficient (APC), Average R-Squared (ARS), dan Average Adjusted $R$-Squared (AARS) model PLS dalam penelitian ini dapat diterima.

Indeks average block VIF (AVIF) menghasilkan nilai 
1,763. Hal ini menunjukkan nilai tersebut lebih kecil dari 5 . Dengan demikian berdasarkan indeks average block VIF (AVIF) model PLS dalam penelitian ini dapat diterima. Kemudian indeks Average Full Collinearity VIF (AFVIF) menghasilkan nilai 1,841 . Hal ini menunjukkan nilai tersebut lebih kecil dari 5. Dengan demikian berdasarkan indeks Average Full Collinearity VIF (AFVIF) model PLS dalam penelitian ini dapat diterima atau dengan kata lain model PLS dalam penelitian ini tidak mengandung multikolinieritas.

Indeks Tenenhaus GoF (GoF) menghasilkan nilai 0,555. Hal ini menunjukkan nilai tersebut lebih besar dari 0.36 . Dengan demikian berdasarkan indeks Tenenhaus GoF (GoF) model PLS dalam penelitian ini dinyatakan memiliki kekuatan prediksi yang tinggi / kuat. Indeks Sympson's Paradox Ratio (SPR) menghasilkan nilai sebesar 1.000. Hal ini menunjukkan nilai tersebut lebih besar dari 0.7 yang berarti $70 \%$ atau lebih dari path di dalam model bebas dari Simpson's Paradox. Indeks $R$-Squared Contribution Ratio (RSCR) menghasilkan nilai sebesar 1.000, yang menunjukkan bahwa lebih besar dari 0.9 yang berarti $90 \%$ atau lebih dari path di dalam model tidak berhubungan dengan kontribusi R-squared negatif. Indeks Statistical Suppression Ratio (SSR) menghasilkan nilai sebesar 1.000, yang menunjukkan bahwa lebih besar dari 0.7 yang berarti $70 \%$ atau lebih dari path di dalam model bebas dari statistikal suppression. Indeks Nonlinear Bivariate Causality Direction Ratio (NLBCDR) menghasilkan nilai sebesar 1.000, yang menunjukkan bahwa lebih besar dari 0.7 yang berarti $70 \%$ atau lebih path yang berhubungan di dalam model mendukung untuk dibalik hipotesis dari hubungan kausalitas yang lemah.

Dengan demikian berdasarkan indeks Sympson's Paradox Ratio (SPR), R- Squared Contribution Ratio (RSCR), Statistical Suppression Ratio (SSR), dan Nonlinear Bivariate Causality Direction Ratio (NLBCDR) maka model PLS dalam penelitian ini dapat diterima.

\section{Uji Hipotesis}

\section{[Figure 2 about here.]}

Berdasar gambar 2 dapat dikatakan bahwa:

$\mathrm{H}_{1}$ : Terdapat pengaruh positif dan signifikan antara keterlibatan pemakai terhadap kinerja sistem informasi akuntansi. Berdasarkan gambar diatas dapat dijelaskan koefisien jalur sebesar 0,379 dengan $\mathrm{P}$ Value sebesar $<0,001$ yang berarti $<0,05$. Dengan demikian H1 diterima.

$\mathrm{H}_{2}$ : Terdapat pengaruh positif dan signifikan antara pelatihan dan pendidikan terhadap kinerja sistem informasi akuntansi. Berdasarkan gambar diatas dapat dijelaskan koefisien jalur sebesar 0,192 dengan P Value sebesar 0,023 yang berarti < 0,05 . Dengan demikian $\mathrm{H} 2$ diterima.

$\mathrm{H}_{3}$ : Terdapat pengaruh positif dan signifikan antara dukungan manajemen puncak terhadap kinerja sistem informasi akuntansi. Berdasarkan tabel 4.16 dapat dijelaskan koefisien jalur sebesar 0,178 dengan $\mathrm{P}$ Value sebesar $<0,032$ yang berarti $<0,05$. Dengan demikian H3 diterima.

\section{Pembahasan \\ Pengaruh Keterlibatan Pemakai terhadap Kinerja Sistem Informasi Akuntansi}

Berdasarkan penelitian ini dapat diketahui bahwa terdapat pengaruh yang positif dan signifikan antara keterlibatan pemakai terhadap kinerja sistem informasi akuntansi pada Rumah Sakit Onkologi Sentani Malang sebesar 0,379 dengan $\mathrm{P}$ Value sebesar $<0,001$ yang berarti $<0,05$. Hal ini berarti semakin tingginya keterlibatan pemakai, maka cenderung dapat meningkatkan kinerja sistem informasi.

Hasil penelitian ini sesuai dengan penelitian sebelumnya yang dilakukan oleh (Rivaningrum \& Mahmud, 2015) yang mengatakan bahwa keterlibatan pemakai berpengaruh positif terhadap kinerja sistem informasi akuntansi. Selanjutnya Soegiharto dalam (Marfuah \& Handoko, 2012) juga mengatakan secanggih apapun sistem informasi yang dibuat, bila dalam perancangan sistemnya tidak memperhatikan faktor manusia pengguna, maka dapat dipastikan terjadinya beberapa hambatan yang disebabkan karena ketidaksesuaian antar sistem penggunanya. Kemudian (Fung Jen, 2002) juga berpendapat bahwa keterlibatan pengguna yang semakin sering akan meningkatkan kinerja sistem informasi akuntansi dikarenakan adanya hubungan yang positif antara keterlibatan pengguna dalam proses pengembangan sistem informasi dalam kinerja sistem informasi akuntansi.

Hasil tersebut didukung oleh hasil analisis deskriptif yang menunjukkan nilai mean tertinggi yaitu pada item 1 variabel keterlibatan pemakai dengan pernyataan "Saya ikut berpartisipasi dalam proses pengembangan sistem" dan pada item 1 variabel kinerja sistem informasi akuntansi dengan pernyataan "Sistem yang ada di departemen mampu membantu departemen berfungsi dengan baik" yang memiliki makna bahwa sebagian besar karyawan rumah sakit ikut berpartisipasi dalam pengembangan sistem, karena dengan adanya sistem dapat membantu rumah sakit berfungsi dengan baik.

Hasil penelitian ini didukung dengan deskripsi responden yang memiliki jumlah responden terbesar berasal dari kalangan yang berlatar belakang pendidikan sarjana $(51,8 \%)$ dan jumlah responden terbanyak berdasarkan profesi sebesar duapuluh sembilan koma tujuh persen( $29,7 \%$ ) responden berprofesi sebagai tenaga non medis seperti admin, kasir, staf dan sebagainya Hal itu menandakan bahwa responden yang memiliki gelar sarjana dan responden yang berprofesi sebagai tenaga non medis selalu ikut berpartisipasi dalam proses pengembangan sistem karena mereka berfikir dengan semakin berkembangnya sistem maka akan semakin meningkatkan kinerja sistem informasi akutansi di Rumah Sakit Onkologi Sentani.

\section{Pengaruh Pelatihan dan Pendidikan terhadap Kinerja Sistem Informasi Akuntansi}

Berdasarkan penelitian ini dapat diketahui bahwa terdapat pengaruh yang positif dan signifikan antara pelatihan dan pendidikan terhadap kinerja sistem informasi akuntansi pada Rumah Sakit Onkologi Sentani Malang sebesar 0,192 dengan $\mathrm{P}$ Value sebesar 0,023 yang berarti < 0,05. Hal ini berarti semakin tinggi adanya pelatihan dan pendidikan maka cenderung dapat meningkatkan kinerja sistem informasi akuntansi.

Hasil penelitian ini sesuai dengan penelitian sebelumnya yang dilakukan oleh (Diansari dkk., 2020) dan (Ane \& Anggraini, 2012) yang mengatakan bahwa "pelatihan dan pendidikan berpengaruh positif terhadap kinerja sistem informasi akuntansi”. Selanjutnya (Prabowo dkk., 2013) juga 
mengatakan bahwa "tujuan diadakanya program pendidikan dan pelatihan pemakai yaitu untuk meningkatkan kemampuan dan pemahaman pemakai terhadap sistem informasi akuntansi yang akan digunakan".

Hasil tersebut didukung hasil analisis deskriptif yang menunjukkan nilai mean tertinggi yaitu pada item 1 variabel pelatihan dan pendidikan dengan pernyataan "Departemen memiliki program pelatihan dan pendidikan guna mengajarkan cara pemakaian sistem yang benar kepada staff" dan pada item 1 variabel kinerja sistem informasi akuntansi dengan pernyataan "Sistem yang ada di departemen mampu membantu departemen berfungsi dengan baik" yang memiliki makna bahwa pada Rumah Sakit Onkologi Sentani terdapat pendampingan diawal pemakaian terhadap pemakai dalam menggunakan sistem informasi akuntansinya sehingga pemakai memiliki pengetahuan dan kemampuan menggunakan sistem informasi akuntansi yang ada, sehingga dapat membantu rumah sakit berfungsi dengan baik.

Hal ini diperkuat deskripsi responden di atas bahwa responden yang memiliki gelar sarjana dan responden yang berprofesi sebagai tenaga non medis telah mengikuti program pelatihan dan pendidikan sehingga memiliki pengetahuan dan kemampuan guna membantu departemen agar dapat berfungsi dengan baik.

\section{Pengaruh Dukungan Manajemen Puncak terhadap Kinerja Sistem Informasi Akuntansi}

Berdasarkan penelitian ini dapat diketahui bahwa terdapat pengaruh yang positif dan signifikan antara dukungan manajemen puncak terhadap kinerja sistem informasi akuntansi pada Rumah Sakit Onkologi Sentani Malang sebesar 0,178 dengan $\mathrm{P}$ Value sebesar $<0,032$ yang berarti $<$ 0,05 . Hal ini berarti semakin tinggi dukungan manajemen puncak yang diberikan, maka cenderung dapat meningkatkan kinerja sistem informasi akuntansi.

Hasil penelitian ini sesuai dengan penelitian sebelumnya yang dilakukan oleh (Rivaningrum \& Mahmud, 2015) dan (Prabowo dkk., 2013) yang mengatakan bahwa "dukungan manajemen puncak berpengaruh positif terhadap kinerja sistem informasi akuntansi. Variabel dukungan manajemen puncak dipandang sebagai salah satu faktor yang dapat mengukur seberapa berhasilnya tingkat kinerja sistem informasi akuntansi”. Menurut (Saebani \& Muliawati, 2016) jika " kinerja sistem informasi akuntansi pada suatu perusahaan itu buruk, maka perusahaan perlu melihat dukungan manajemen puncak yang telah diberikan kepada karyawan yang menggunakan sistem informasi akuntansi dalam perusahaan apakah cocok atau tidak, sehingga berdampak langsung terhadap penilaian kinerja sistem informasi akuntansi di perusahaannya".

Hasil tersebut didukung oleh hasil analisis deskriptif yang menunjukkan nilai mean tertinggi yaitu pada item 1 variabel dukungan manajemen puncak dengan pernyataan "Manajemen puncak mahir dalam menggunakan komputer" dan pada item 1 variabel kinerja sistem informasi akuntansi dengan pernyataan "Sistem yang ada di departemen mampu membantu departemen berfungsi dengan baik" yang memiliki makna bahwa manajemen puncak yang ada di Rumah Sakit Onkologi Sentani dipandang mahir dalam menggunakan komputer, sehingga dapat memberi motivasi kepada bawahannya agar dapat mengembangkan sistem guna membantu rumah sakit dapat berfungsi dengan baik.

Hal ini menunjukkan bahwa responden yang memiliki gelar sarjana dan responden yang berprofesi sebagai tenaga non medis merasakan adanya dukungan manajemen puncak dalam pengembangan sistem yang ada dirumah sakit, sehingga membantu rumah sakit agar dapat berfungsi dengan baik.

\section{KESIMPULAN}

Berdasarkan hasil penelitian menunjukkan terdapat pengaruh positif dan signifikan antara keterlibatan pemakai, pelatihan dan pendidikan, serta dukungan manajemen puncak terhadap kinerja sistem informasi akuntansi pada Rumah Sakit Onkologi Sentani Malang.

Keterbatasan penelitian ini yaitu penelitian hanya dilakukan pada karyawan yang terlibat dalam penggunaan sistem informasi akuntansi di Rumah Sakit Onkologi Sentani Malang saja, sehingga untuk mendapatkan kesimpulan yang bersifat secara general maka perlu dilakukan penelitian yang lebih luas dengan menambahkan obyek penelitian lebih dari satu rumah sakit. Hanya menguji pengaruh keterlibatan pemakai, pelatihan dan pendidikan, serta dukungan wawancara langsung dengan responden sehingga jawaban responden belum tentu menggambarkan keadaan sebenamya.

Saran penelitian ini bagi instansi Rumah Sakit Onkologi Sentani Malang untuk tetap meningkatkan adanya keterlibatan pengguna, program pelatihan dan pendidikan, serta dukungan manajemen puncak dalam pengembangan sistem. Karena semakin tinggi adanya ketiga faktor tersebut maka kinerja sistem informasi akuntansi juga akan semakin meningkat. Kemudian bagi peneliti selanjutnya untuk menambah variabel lain seperti ukuran perusahaan dan variabel yang lain yang dapat mempengaruhi kinerja sistem informasi akuntansi agar hasil lebih maksimal, dan juga dapat menambahkan tempat penelitian BLU tidak hanya pada Rumah Sakit saja, sehingga dapat menambah jumlah responden.

\section{REFERENCES}

Almilia, L. S., Si, M., \& Briliantien, I. (2014). Faktor-Faktor Yang Mempengaruhi Kinerja Sistem Informasi Akuntansi Pada Faktor-Faktor Yang Mempengaruhi Kinerja Sistem Informasi Dan Sidoarjo. February.

Almillia \& Briliantien. (2007). Faktor-Faktor Yang Mempengaruhi Kinerja Sistem Informasi Akuntansi Pada Bank Umum Pemerintah Di Wilayah Surabaya Dan Sidoarjo. Jurnal Akuntansi Stie Perbanas, 2(10), 24-43.

Ane, L., \& Anggraini, P. N. (2012). Faktor-Faktor Yang Mempengaruhi Kinerja Sistem Informasi Akuntansi Di Lingkungan Pemerintahan Daerah Serdang Bedagai. Jurnal Telaah Akuntansi (Juta) Issn : 1693-6760, 14(02), 16-30.

Chomasatu, Y. (2014). Faktor - Faktor Yang Mempengaruhi Performance Of Accounting Information Systems. Jurnal Paradigma Universitas Islam Batik Surakarta, 12(01), 116288.

Dalimunthe, R., Agusti, R., \& Fitrios, R. (2014). Analisis FaktorFaktor Yang Mempengaruhi Kinerja Sistem Informasi Akuntansi Pada Perusahaan Perhotelan Yang Ada Di Riau Dan Sumatera Barat. Jurnal Online Mahasiswa Fakultas 
Ekonomi Universitas Riau, 1(2), 1-15.

Diansari, L. M., Sujana, I. K., Ayu, I. G., \& Budiasih, N. (2020). User Involvement, Training And Education Of The User, Formalization Of The Development Of Information System And Support Of Top Management To The Performance Of Udayana University Accounting Information Systems: Organizational Commitments As Moderate V. 7(4), 65-79.

Dwinda, M. K. (2015). Pengaruh Keterlibatan Pengguna Dan Ukuran Organisasi Pada Efektivitas Sistem Informasi Akuntansi. E-Jurnal Akuntansi Udayana, 10(3), 867-881.

Ferawati Dan Purwanto. (2015). Analisis Faktor-Faktor Yang Mempengaruhi Kinerja Sistem Informasi Akuntansi ( Studi Kasus Pada Pt. Cahya Mitra Pratama Madiun). Stie Dharma Iswara Madiun, 5(2), 25-33.

Fung Jen, T. (2002). Faktor- Faktor Yang Mempengaruhi Kinerj Sistem Informasi Akuntansi. Jurnal Bisnis Dan Akuntansi, Iv No. 2.

Komara, A. (2005). Analisis Faktor-Faktor Yang Mempengaruhi Kinerja Sistem Informasi Akuntansi Drs. Acep Komara, Se., Msi. Universitas Swadaya Gunung Jati Cirebon. Organization, September, 15-16.

Ladewi, Y., \& Nurhayati, N. (2015). The Influence Of Personal Information System Capabilities , Top Management Support. Training And Education Program Performance Of Accounting Information Systems Implications The Quality Of Accounting Information In The Province Of Islamic Banks Of West J. Research Journal Of Finance And Accounting, 6(3), 5-12.

Manek, M. Andreani., \& Santoso, S. (2019). Surakarta Accounting Review ( Sarev ). 1(1), 26-33.

Mardiana, I. G. E. P., Sinarwati, N. K., \& Atmadja, A. T. (2014). Analisis Faktor-Faktor Yang Mempengaruhi Kinerja Sistem Informasi Akuntansi (Sia) Pada Lembaga Perkreditan Desa (Lpd) Di Kecamatan Susut. E-Journal S1 Ak Universitas Pendidikan Ganesha, 2(1).

Marfuah, M., \& Handoko, A. (2012). Determinan Kinerja Sistem Informasi Akuntansi: Studi Empiris Pada Bank Syariah Di Wilayah Daerah Istimewa Yogyakarta. Jurnal Ekonomi Dan Keuangan Islam, 2(1), 52-63.

Mulyadi. (2010). Sistem Akuntansi (Edisi Keti). Salemba Empat.

Prabowo, R. R., Sukirman, \& Hamidi, N. (2013). Faktor-Faktor Yang Mempengaruhi Kinerja Sistem Informasi Akuntansi Di Bank Umum Kota Surakarta. Journal Of Chemical Information And Modeling, 53(9), 1689-1699. Https://Doi.Org/10.1017/Cbo9781107415324.004

Rivaningrum, A., \& Mahmud, A. (2015). Faktor-Faktor Yang Mempengaruhi Kinerja Sia Pada Rumah Sakit Saras Husada Purworejo. Accounting Analysis Journal, 4(2), 1-7. Https://Doi.Org/10.15294/Aaj.V4i2.7811

Saebani, A., \& Muliawati, A. (2016). Analisis Faktor-Faktor Yang Memengaruhi Kinerja Sistem Informasi Akuntansi. E-Jurnal Akuntansi, 14(3), 1782-1809.

Santoso, T., \& Tjiptono, F. (2001). Riset Pemasaran: Konsep
Dan Aplikasi Dengan Spss. Pt Elex Media Komputindo.

Shien, M. J. (2015). Influence Of User Ability And Top Management Support On The Quality Of Accounting Information System And Its Impact On The Quality Of Accounting Information. 2.

Sugiyono. (2016). Metode Penelitian Kuantitatif, Kualitatif, Dan R \& D. Alfabeta.

Utama, I. D. G. B., \& Suardhika, I. M. S. (2009). Faktor-Faktor Yang Mempengaruhi Kinerja Sistem Informasi Akuntansi Pada Lembaga Perkreditan Desa. E-Jurnal Akuntansi Universitas Udayana, 3(3), 728-746.

Copyright (C) 2020 and. This is an open-access article distributed under the terms of the Creative Commons Attribution License (CC BY). The use, distribution or reproduction in other forums is permitted, provided the original author(s) and the copy-right owner(s) are credited and that the original publication in this journal is cited, in accordance with accepted academic practice. No use, distribution or reproduction is permitted which does not comply with these terms. 


\section{LIST OF TABLES}

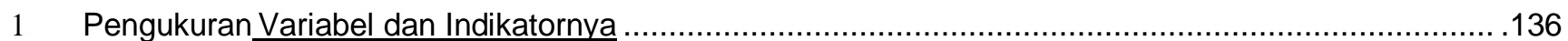

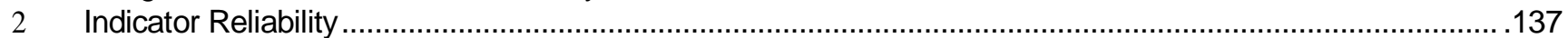

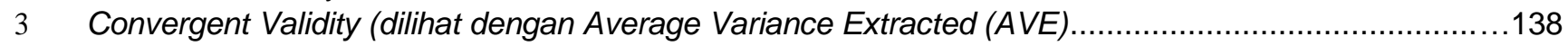

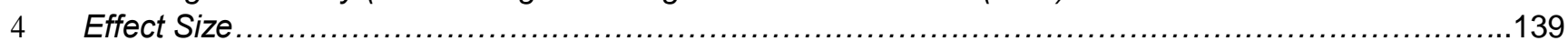

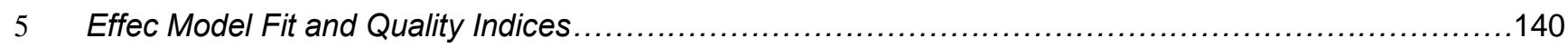


TABEL 1 | Variabel dan Indikatornya

\begin{tabular}{|c|c|c|c|}
\hline No. & Variabel & Definisi & Indikator \\
\hline & \multicolumn{3}{|c|}{ Variabel Dependen: } \\
\hline & \multirow{3}{*}{$\begin{array}{l}\text { Kinerja } \\
\text { Sistem } \\
\text { Informasi } \\
\text { Akuntansi }\end{array}$} & \multirow{3}{*}{$\begin{array}{lr}\text { Kinerja } & \text { sistem } \\
\text { informasi } & \text { akuntansi } \\
\text { untuk } & \text { menunjang } \\
\text { tercapainya } r \text { tujuan } & \text { yang dapat terlihat } \\
\text { melalui } & \text { kepuasan } \\
\text { pemakai } & \text { sistem } \\
\text { informasi akuntansi } & \text { akunan } \\
\text { dan dari pemakaian } & \text { sistem informasi } \\
\text { akuntansi } & \text { (Saebani \& } \\
\text { Muliawati, 2016) } \\
\text { Diukur dengan } \\
\text { skala respon. }\end{array}$} & $\begin{array}{lr}\text { Kepuasan } & \text { pemakai } \\
\text { dari } & \text { pemakaian } \\
\text { sistem } & \text { informasi } \\
\text { akuntansi } & \\
\end{array}$ \\
\hline & & & \multirow[t]{2}{*}{$\begin{array}{l}\text { Pemakaian yang } \\
\text { mudah dari sistem } \\
\text { informasi akuntansi }\end{array}$} \\
\hline & & & \\
\hline \multicolumn{4}{|c|}{ Variabel Independen: } \\
\hline \multirow[t]{2}{*}{1.} & \multirow{2}{*}{$\begin{array}{l}\text { Keterlibatan } \\
\text { Pemakai } \\
\text { Sistem } \\
\text { Informasi } \\
\text { Akuntansi }\end{array}$} & \multirow{2}{*}{$\begin{array}{l}\text { Keterlibatan pemakai } \\
\text { sistem untuk } \\
\text { pengembangan dan } \\
\text { implementasi sistem. } \\
\text { (Prabowo, Sukirman, } \\
\text { \& Nurhasan, 2013) } \\
\text { Di ukur dengan } 5 \\
\text { skala respon. }\end{array}$} & $\begin{array}{l}\text { Partisipasi pemakai } \\
\text { dalam } \\
\text { proses implementasi } \\
\text { sistem informasi } \\
\text { akuntansi }\end{array}$ \\
\hline & & & $\begin{array}{l}\text { Tingkat pengaruh } \\
\text { pemakai dalam } \\
\text { pengembangan } \\
\text { system }\end{array}$ \\
\hline
\end{tabular}

\begin{tabular}{|c|c|c|c|}
\hline \multirow[t]{2}{*}{2.} & \multirow{2}{*}{$\begin{array}{l}\text { Pelatihan dan } \\
\text { Pendidikan }\end{array}$} & \multirow{2}{*}{$\begin{array}{l}\text { Pelatihan dan } \\
\text { pendidikan mengenai } \\
\text { pengetahuan sistem } \\
\text { informasi akuntansi } \\
\text { (Rivaningrum \& } \\
\begin{array}{l}\text { Mahmud, 2015) } \\
\text { Diukur dengan } \\
\text { skala respon. }\end{array}\end{array}$} & $\begin{array}{l}\text { Efektivitas } \\
\text { pelatihan rogram } \\
\text { pendidikan sisyem } \\
\text { dan cara pemakaian } \\
\text { system }\end{array}$ \\
\hline & & & $\begin{array}{l}\text { Kebermanfaatan } \\
\text { program pelatihan } \\
\text { dan pendidikan } \\
\text { dapat meningkatkan } \\
\text { kinerjar sistem } \\
\text { informasi akuntansi }\end{array}$ \\
\hline \multirow[t]{3}{*}{3.} & \multirow[t]{3}{*}{$\begin{array}{l}\text { Dukungan } \\
\text { Manajemen } \\
\text { Puncak }\end{array}$} & \multirow{3}{*}{$\begin{array}{l}\text { Dukungan } \\
\text { manajemen puncak } \\
\text { adalah keterlibatan } \\
\text { manajer dalam } \\
\text { kemajuan proyek dan } \\
\text { menyediakan sumber } \\
\text { daya yang diperlukan } \\
\text { (Saebani \& Muliawati, } \\
\text { 2016). } \\
\text { Diukur dengan } 5 \\
\text { skala respon. }\end{array}$} & $\begin{array}{l}\text { Kemahiran } \\
\text { manajemen puncak } \\
\text { dalam } \\
\text { menggunakan } \\
\text { komputer dapat } \\
\text { mencapai efektifitas } \\
\text { sistem infromasi } \\
\text { akuntansi }\end{array}$ \\
\hline & & & $\begin{array}{l}\text { Keterlibatan } \\
\text { manajemen puncak } \\
\text { secara aktif dalam } \\
\text { perencanaan } \\
\text { operasi sistem } \\
\text { informasi }\end{array}$ \\
\hline & & & $\begin{array}{l}\text { Perhatian } \\
\text { manajemen puncak } \\
\text { yang tinggi dapat } \\
\text { meningkatkan } \\
\text { kinerja sistem } \\
\text { informasi akuntansi }\end{array}$ \\
\hline
\end{tabular}


TABEL 2 | Indicator Reliability

\begin{tabular}{|c|c|c|c|c|c|}
\hline Variabel & Item & $\begin{array}{l}\text { Loading } \\
\text { Factor }\end{array}$ & SE & P Value & Keterangan \\
\hline & $X_{1.1}$ & 0,844 & 0,094 & $<0,001$ & Reliabel \\
\hline Keterlibatan & $\mathrm{X}_{1.2}$ & 0,945 & 0,094 & $<0,001$ & Reliabel \\
\hline \multirow[t]{3}{*}{ Pemakai (X1) } & $\mathrm{X}_{1.3}$ & 0,955 & 0,094 & $<0,001$ & Reliabel \\
\hline & $\mathrm{X}_{1.4}$ & 0,907 & 0,094 & $<0,001$ & Reliabel \\
\hline & $\mathrm{X}_{2.1}$ & 0,846 & 0,094 & $<0,001$ & Reliabel \\
\hline Pelatihan dan & $\mathrm{X}_{2.2}$ & 0,852 & 0,094 & $<0,001$ & Reliabel \\
\hline \multirow[t]{2}{*}{ Pendidikan (X2) } & $\mathrm{X}_{2.3}$ & 0,899 & 0,094 & $<0,001$ & Reliabel \\
\hline & $\mathrm{X}_{2.4}$ & 0,895 & 0,094 & $<0,001$ & Reliabel \\
\hline Dukungan & $\mathrm{X}_{3.1}$ & 0,788 & 0,094 & $<0,001$ & Reliabel \\
\hline Manajemen & $X_{3.2}$ & 0,952 & 0,094 & $<0,001$ & Reliabel \\
\hline \multirow[t]{3}{*}{ Puncak (X3) } & $\mathrm{X}_{3.3}$ & 0,927 & 0,094 & $<0,001$ & Reliabel \\
\hline & $Y_{1}$ & 0,704 & 0,094 & $<0,001$ & Reliabel \\
\hline & $Y_{2}$ & 0,661 & 0,094 & $<0,001$ & Reliabel \\
\hline Kinerja Sistem & $Y_{3}$ & 0,624 & 0,094 & $<0,001$ & Reliabel \\
\hline Informasi & $\mathrm{Y}_{4}$ & 0,788 & 0,094 & $<0,001$ & Reliabel \\
\hline \multirow[t]{3}{*}{ Akuntansi (Y) } & $Y_{5}$ & 0,850 & 0,094 & $<0,001$ & Reliabel \\
\hline & $Y_{6}$ & 0,837 & 0,094 & $<0,001$ & Reliabel \\
\hline & $Y_{7}$ & 0,815 & 0,094 & $<0,001$ & Reliabel \\
\hline
\end{tabular}

Sumber: Data Diolah Oleh Peneliti 2020 
TABEL 3 | Convergent Validity (dilihat dengan Average Variance Extracted (AVE)

\begin{tabular}{lc}
\hline \multicolumn{1}{c}{ Variabel } & AVE \\
Keterlibatan pemakai $\left(\mathrm{X}_{1}\right)$ & 0,835 \\
Pelatihan dan Pendidikan $\left(\mathrm{X}_{2}\right)$ & 0,763 \\
Dukungan Manajemen Puncak $\left(\mathrm{X}_{3}\right)$ & 0,795 \\
Kinerja Sistem Informasi Akuntansi $(\mathrm{Y})$ & 0,575
\end{tabular}

AVE

835

0,763

Kinerja Sistem Informasi Akuntansi $(Y)$

0,575

Keterangan

Valid

Valid

Valid

Valid 
TABEL 4 | Effect Size

\begin{tabular}{l}
\multicolumn{1}{c}{ Variabel } \\
Keterlibatan Pemakai $\left(\mathrm{X}_{1}\right)-$ Kinerja SIA $(\mathrm{Y})$ \\
Pelatihan dan Pendidikan $\left(\mathrm{X}_{2}\right)-$ Kinerja SIA $(\mathrm{Y})$ \\
Dukungan Manajemen Puncak $\left(\mathrm{X}_{3}\right)-$ Kinerja SIA $(\mathrm{Y})$
\end{tabular}

Effect Size

0,227

0,095

Sumber: Data Diolah Oleh Peneliti 2020 
TABEL 5 | Model Fit and Quality Indices

\begin{tabular}{|c|c|c|}
\hline Model Fit and Quality Indices & Hasil & Kriteria \\
\hline Average path coefficient (APC) & $0,250, P=0,003$ & $\begin{array}{l}P \text { value } \leq 0,05 \text { (significance } \\
\text { level }=5 \% \text { ) }\end{array}$ \\
\hline Average R-squared (ARS) & $0,416, P<0,001$ & $\begin{array}{l}P \text { value } \leq 0,05 \text { (significance } \\
\text { level }=5 \%)\end{array}$ \\
\hline Average adjusted R-squared (AARS) & $0,381, P<0,001$ & $\begin{array}{l}P \text { value } \leq 0,05 \text { (significance } \\
\text { level }=5 \% \text { ) }\end{array}$ \\
\hline Average block VIF (AVIF) & 1,763 & Acceptable if $<=5$, ideally $<=3,3$ \\
\hline $\begin{array}{l}\text { Average full collinearity VIF } \\
\text { (AFVIF) }\end{array}$ & 1,841 & Acceptable if $<=5$, ideally $<=3,3$ \\
\hline Tenenhaus GoF (GoF) & 0,555 & $\begin{array}{l}\text { Small }>=0,1, \text { medium }>=0,25, \text { large }>= \\
0,36\end{array}$ \\
\hline Sympson's paradox ratio (SPR) & 1.000 & Acceptable if $>=0,7$, ideally $=1$ \\
\hline R-squared contribution ratio (RSCR) & 1.000 & Acceptable if $>=0,9$, ideally $=1$ \\
\hline Statistical suppression ratio (SSR) & 1.000 & Acceptable if $>=0,7$ \\
\hline $\begin{array}{l}\text { Nonlinear } \quad \text { bivariate causality } \\
\text { direction ratio (NLBCDR) }\end{array}$ & 1.000 & Acceptable if $>=0,7$ \\
\hline
\end{tabular}




\section{LIST OF FIGURES}

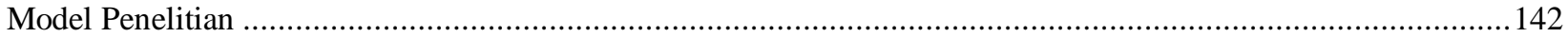

2 Hasil Output PLS

143 
Figure 1/ Model Penelitian

Keterlibatan Pemakai $\left(X_{1}\right)$


Figure 2/ Hasil Output PLS

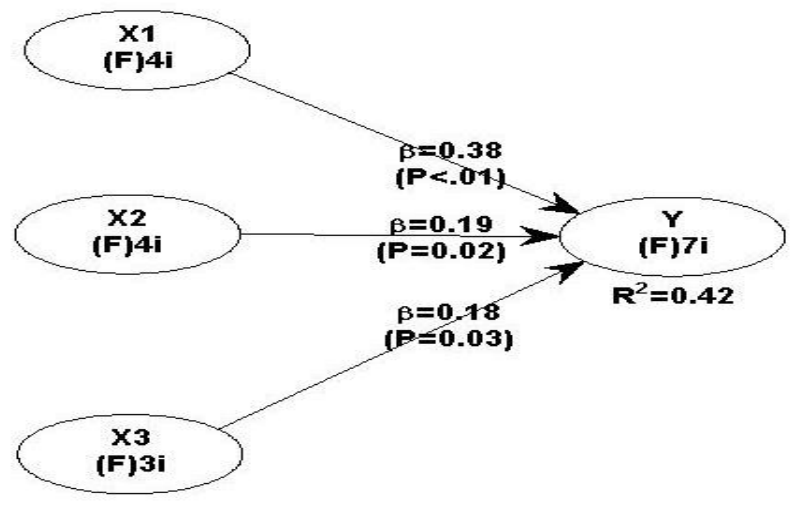

